\title{
Rozvíjanie digitálnych vzt'ahov a digitálnej dôvery so zákazníkmi v rámci prechodu na Industry 4.0
}

\author{
Peter Malega ${ }^{1}$, Juraj Kováč ${ }^{1}$, Vladimír Rudy ${ }^{1}$ \\ 1 Technická univerzita, Strojnícka fakulta - Ústav priemyselného inžinierstva, manažmentu a \\ inžinierstva prostredia \\ Park Komenského 9, 04200 Košice, Slovensko \\ peter.malega@tuke.sk \\ juraj.kovac@tuke.sk \\ vladimir.rudy@tuke.sk
}

\begin{abstract}
Anotácia: Tradičný model riadenia vzt’ahov a budovania dôvery so zákazníkmi sa v súčasnej dobe vd’aka viacerým okolnostiam mení. Najzávažnejšími pričinami sú neustále sa zrýchlujúca dynamika trhu, vplyv pandémie Covid-19 na trh, ale predovšetkým prechod na Industry 4.0. V rámci tohto prechodu sa spoločnosti musia prispôsobit' novým, zmeneným podmienkam, kde už tradičné modely $v$ zásade nefungujú a je potrebné ich zásadným spôsobom prispôsobit', resp. uplatňovat' úplne nové. Dnešné moderné platformy na budovanie digitálnych vzt'ahov a digitálnej dôvery so zákazníkmi prinášajú $v$ určitom ohl'ade vel'ké ul'ahčenie, avšak $v$ inom ohlade si vyžadujú mnohé nové zručnosti a kombináciu vedomostí a schopností na ich úspešné zvládnutie, čo možno chápat' ako výzvu, pred ktorou prechod na Industry 4.0 stojí.
\end{abstract}

\section{1 Úvod}

Rozvojom Industry 4.0 bude postupne slabnút' tradičný model, kde sú výrobky uvádzané na trh metódou „push“ a čoraz viac sa bude presadzovat' „pull“ model, v ktorom zákazníci budú užšie zapojení do spolupráce $s$ výrobcami. Industry 4.0 prinesie nové príležitosti na udržiavanie a utužovanie takýchto vzt’ahov, ale zároveň zosilní aj boj o každého zákazníka. [1, 4]

Napríklad metóda Kanban je nástroj na implementáciu „pull“ výroby za zákazníka a podporuje nepretržitý tok materiálu s bezodpadovými procesmi pri zachovaní vopred definovanej úrovne zásob, aby sa zabezpečila neprerušená dodávka materiálu.

Je potrebné poznamenat', že nedostatočné sledovanie množstva materiálu dodávaného na výrobnú linku, ako aj zmeny $v$ harmonograme výroby, by mohli tento „pull“ systém výrazne zmenit'. [3, 9]

Zmeny vo výrobných procesoch, regulačných skladoch, alebo dobách cyklu, si vyžadovali komplikované úpravy kariet Kanban. Tieto variácie obmedzili primeranost' pre individuálne a prispôsobené výrobky alebo výrobky s kratšími životnými cyklami. 


\subsection{Prehlbovanie vzt'ahov so zákazníkmi pomocou spoluvytvárania a prispôsobovania sa jeho potrebám}

Digitálna integrácia so zákazníkom a nové technologické možnosti presunút' výrobu bližšie k zákazníkovi (ako napr. prostredníctvom 3D tlače) umožní väčšiu osobitost' a customizáciu produktov. Väčšina spoločností očakáva posilnenie ponuky digitálnych služieb, a to bud' digitalizáciou už existujúcich produktov, alebo vývojom nových digitálnych produktov.

Je to príležitost' nielen rýchlejšie a pružnejšie reagovat' na požiadavky zákazníka, ale tiež predpovedat' jeho potreby, čo môže pomôct' zákazníkovi napredovat' tým správnym smerom.

\subsection{Aplikácia metód na využitie dát pre zvýšenie flexibility poskytovania služieb zákazníkom}

\subsubsection{Kanban 4.0}

V kontexte priemyslu 4.0 sú však $\mathrm{k}$ dispozícii nové riešenia, ktoré sa dajú začlenit' do systémov Kanban, ako sú Big Data Analytics, AGV (Automated Guided Vehicle) a VS (Virtual Simualtion), ktoré sú syntetizované na obrázku 1.

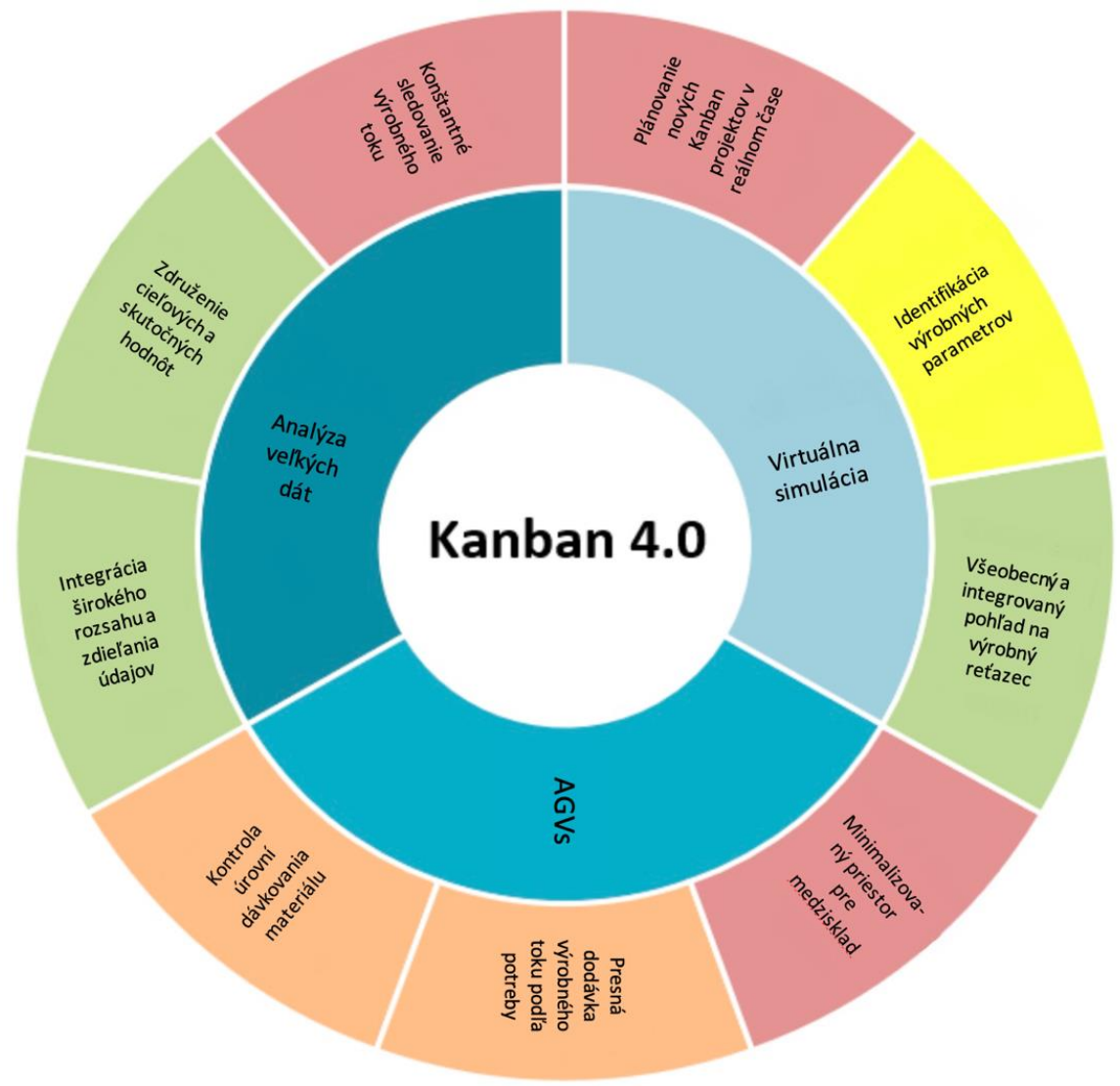

Obrázok 1 - Kanban 4.0: korelácia medzi nástrojom Kanban a technológiami 4.0 [5] 
K dispozícii sú štyri atribúty Lean 4.0, z ktorých dva sú zvýraznené tromi bodmi označovania, ktorými sú integrácia medzi procesmi, zariadeniami a zainteresovanými stranami a minimalizácia a/alebo eliminácia odpadu.

Použitím týchto technológií možno znižit' zásoby medziproduktov na minimum, pretože Big Data Analytics prispieva k monitorovaniu toku výroby v reálnom čase, čo poskytuje automatizovanú logistiku s inteligentnou kontrolou zásob.

Neustála transformácia údajov na informácie z celého výrobného toku je nevyhnutná pre vytvorenie nových systémov Kanban navrhnutých pomocou technológií VS. Táto technológia 4.0 je schopná predstavit' viac perspektív produktívnych kontextov, ktoré predvídajú riešenia a predpovedajú výrobné správanie $s$ ciel'om obmedzit' úzke miesta. AGV zasa dopĺnajú pracovné stanice podla skutočných a presných potrieb výrobnej linky, čím znižujú zásoby, dodacie lehoty a zbytočné pohyby.

$\checkmark$ skutočnosti možno kombináciou systému Kanban s technológiami vyvinút' systém e-Kanban, ktorý nahradí bežné fyzické karty. Tento virtuálny Kanban dokáže rozpoznat' prázdne políčko na spustenie automatického doplňovania, na kontrolu úrovne načítania dávok materiálu a na sledovanie zmien výrobného plánu.

V spojení $\mathrm{s}$ inými technológiami Big Data Analytics neustále sleduje prebiehajúci pracovný tok, akonáhle prijíma údaje $\mathrm{z}$ viacerých zdrojov $\mathrm{z}$ výroby. Táto technológia 4.0 potom zvyšuje transparentnost' pohybov materiálu a procesov a umožňuje kombináciu ciel'ových a skutočných hodnôt na odstránenie nepotrebného materiálu.

\subsubsection{Poka-Yoke 4.0}

Mechanizmus Poka-Yoke podporuje detekciu a elimináciu abnormálnych podmienok vo výrobných procesoch, aby sa zabránilo tvorbe chybných výrobkov. Tento nástroj Lean Manufacturing generuje vynútené sekvencie vo výrobných linkách a kontroluje procesy počas ich vykonávania a zastavuje ich $\checkmark$ prípade chýb a zistených problémov.

Pretože logikou Poka-Yoke je predchádzat' chybám $v$ produkčných systémoch, sú AGV schopné rýchlo sa prispôsobit' možným poruchám toku a informovat' cloud o problémoch, ktoré sa vyskytli, pre neskoršiu analýzu a riešenie. Rozšírená realita (AR - Augmented Reality) zasa spolupracuje so zamestnancami, pomáha im pri manuálnych úlohách, aby sa vyhli možným sklzom, ako aj predstavuje na svojich displejoch pokyny a virtuálne prvky, ktoré ulahčujú porozumenie a vykonávanie činností.

Poka-Yoke $v$ záujme zachovania bezchybného prostredia priamo prispieva $\mathrm{k}$ zlepšeniu bezpečnosti produktívnych operácií, pričom pracuje súčasne so systémami kybernetickej bezpečnosti. Technológia AR ponúka významné výhody ako je rýchlost', spol'ahlivost' a znížená poruchovost', podporuje 
pracovníka $v$ reálnom čase počas manuálnych operácií a pomáha znižovat' l'udské chyby.

Vd’aka prezentácii intuitívnych informácií na svojich displejoch v kombinácii s inteligenciou spolupracovníkov môže AR umožnit' digitálnym systémom PokaYoke funkcie náročné na prácu. Tieto systémy poskytujú vyššiu efektívnost' pri dokončovaní manuálnych úloh, čo minimalizuje výskyt chýb, prepracovanie, nadbytočné kontroly a zvyšuje kvalitu práce.

Vzhl'adom na to, že nástroj LM predchádza, opravuje a upozorňuje operátora na chyby, ked' sa vyskytnú, sú zariadenia Poka-Yoke obzvlášt' užitočné v operáciách vyžadujúcich použitie hardvéru. $V$ tejto súvislosti sa uvádza, že inteligentná implementácia teórií a techník l'udského faktora počas vývoja návrhu hardvéru môže zabránit' zlyhaniam a zabezpečit' vyššiu bezpečnost' pri vykonávaní úloh. Na obrázku 2 je znázornená Poka-Yoke 4.0: korelácia medzi nástrojom Poka-Yoke s technológiami 4.0.

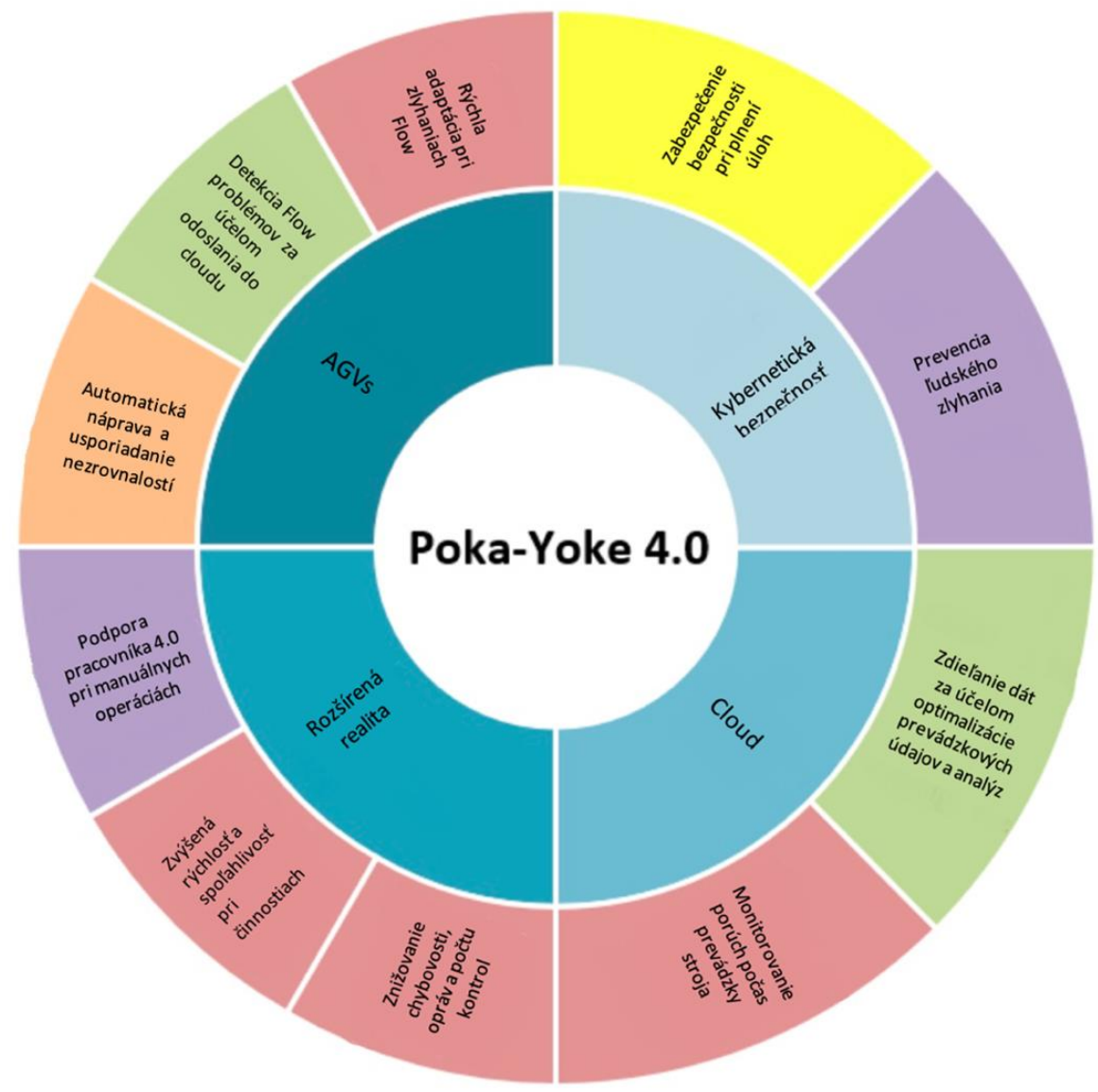

Obrázok 2 - Poka-Yoke 4.0: korelácia medzi nástrojom Poka-Yoke a technológiami 4.0 [10]

\subsubsection{Rozvoj platforiem so zámerom priblížit' sa svojim zákazníkom}

Integrované riešenia ako služby s pridanou hodnotou sa vyznačujú výraznými výhodami pre svojich zákazníkov. Jedným z takýchto riešení je aj využívanie rôznych platforiem, ktoré umožňujú prepojenie rôznych technológií a ulahčujú vzájomnú komunikáciu medzi partnermi horizontálneho hodnotového ret’azca. 
Priekopníci v oblasti Industry 4.0 z radov poskytovatel'ov riešení dokážu z týchto výhod vyt'ažit' maximum. Napríklad spoločnosti GE a Siemens upevňujú svoje pozície tvorcov platforiem. Každá z týchto spoločností vyvinula cloudový systém pre prepojenie strojov a zariadení od rôznych výrobcov, čo umožňuje realizovat' zber a analýzu dát a následnú optimalizáciu celkovej prevádzky, či logistiky. [7]

Cloud poskytuje jednotnú komunikáciu medzi úrovňou technológie (inteligentné produkty a kyberfyzické systémy) a najvyššou úrovňou hierarchie v organizácii. Inovácia, ktorá zvyšuje zdiel'anie údajov za hranice podniku, zvyšuje výkon systému, zvyšuje jeho pružnost' a flexibilitu a znižuje náklady.

Mnohé d'alšie spoločnosti vyvíjajú svoj biznis od jednoduchého doplňania svojich produktov o digitálne funkcionality, cez komplexnejšie digitálne riešenia, až po ambície platformových integrátorov. [10]

Ak má byt' platforma efektívna, musí jej využívanie priblížit' zákazníka $k$ dodávatel'ovi. Priemyselné podniky, ktoré využívajú tieto platformy, budú mat' prístup k zákazníckym dátam, budú ich môct' analyzovat' $s$ ciel'om lepšie predpokladat' potreby zákazníkov a zlepšovat' a vyvíjat' nové produkty. Takáto spolupráca nakoniec vedie k vybudovaniu digitálneho ekosystému. [8]

Na obrázku 3 je znázornené približovanie sa priemyselných podnikov ku svojim zákazníkom.

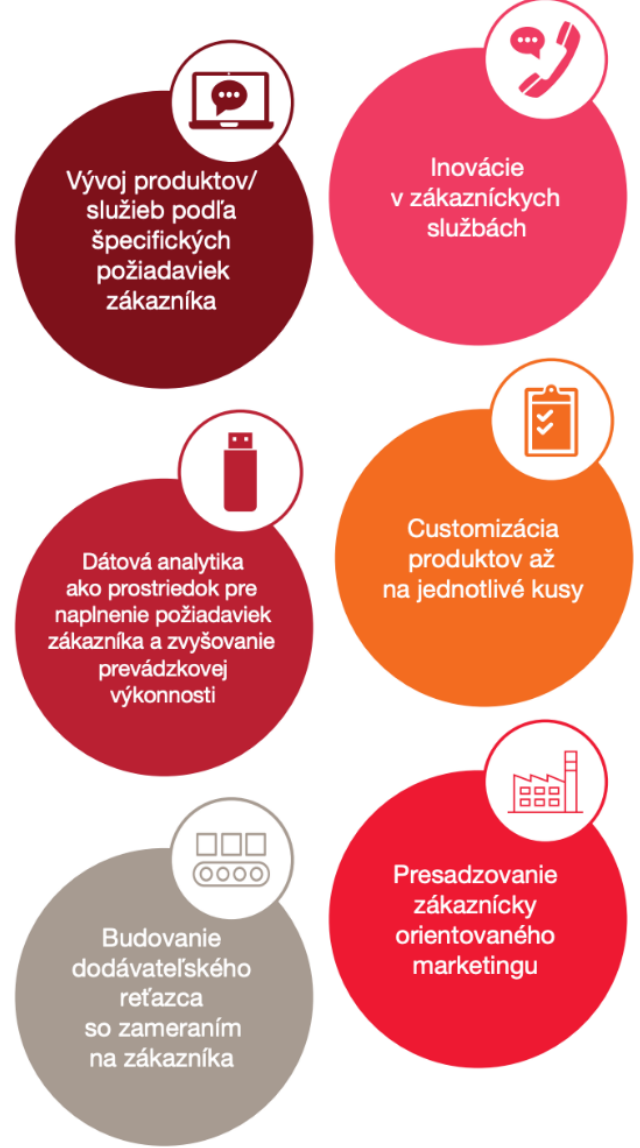

Obrázok 3 - Približovanie sa priemyselných podnikov ku svojim zákazníkom [6] 


\section{Digitálna dôvera a dátová analytika ako základ Industry 4.0}

Dáta sú jadrom štvrtej priemyselnej revolúcie, ale masívne sa zvyšujúci tok informácií bez správnych analytických techník prináša len malú hodnotu.

Rýchlo rastúci počet systémov, senzorov a rôznych zariadení, ako aj zvyšujúca sa integrácia vertikálnych a horizontálnych hodnotových ret’azcov, má za následok masívny nepretržitý tok dát.

Dáta prichádzajú $v$ rôznych formátoch a $z$ rôznych zdrojov (z externých aj interných zdrojov), pričom je nutné navzájom ich kombinovat'. Aby sme z dát získali informácie s pridanou hodnotou, potrebujeme odbornú a efektívnu dátovú analytiku.

Súčasne je potrebné dbat' na zabezpečenie dát spolu so všetkým, čo s tým súvisí a budovat' tak nevyhnutnú digitálnu dôveru.

Na obrázku 4 je znázornené, že dáta a analytické nástroje sú pri rozhodovaní čoraz dôležitejšie a na obrázku 5 je znázornené podceňovanie podnikov v oblasti možností dátových analýz.

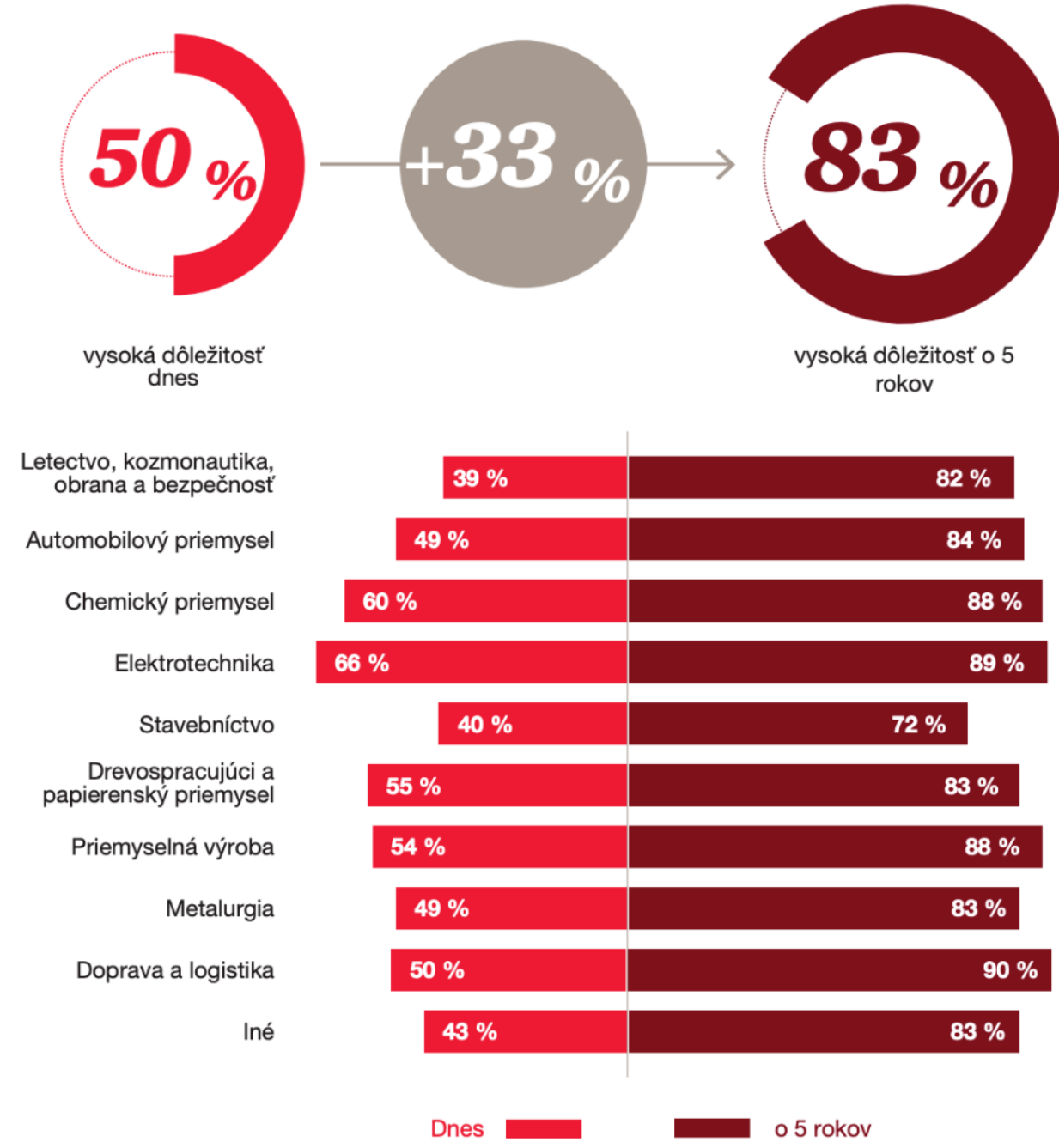

Obrázok 4 - Vzrastajúca dôležitost' dát a analytických nástrojov pri rozhodovaní [11] 
Optimalizácia biznis plánovania a controllingu

Zlepšenie výrobného / prevádzkového plánovania

Zlepšenie vztahahov so zákazníkmi

Efektívnejšie využívanie zariadení

Vývoj nových alebo optimalizácia existujúcich produktov /služieb

Zvýšenie obratu spoločnosti

Optimalizácia nákladov na dopravu a logistiku

Zvýšenie kvality produktov/procesov

Zefektívnenie údržby

Zlepšenie spolupráce s partnermi

\section{$56 \%$} $22 \%$ $78 \%$

\begin{tabular}{|c|c|}
\hline $59 \%$ & \\
\hline $51 \%$ & $21 \%$ \\
\hline $52 \%$ & $19 \%$ \\
\hline
\end{tabular}

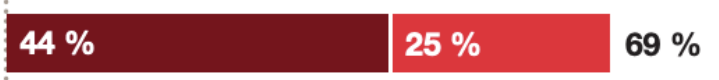

\section{$46 \%$} $22 \%$ $68 \%$

\section{$48 \%$}

$19 \%$ $67 \%$

\section{$47 \%$}

$18 \%$

$65 \%$

\section{$38 \%$}

$23 \%$ $61 \%$

$36 \%$

$20 \%$

$56 \%$

Status quo Potenciál rastu o 5 rokov

Obrázok 5 - Podceňovanie podnikov v oblasti možností dátových analýz [11]

Široké využívanie dát a digitálne ekosystémy vyvolávajú klúčové otázky týkajúce sa kybernetickej bezpečnosti. Čím je miest viac, pri ktorých dochádza k zhromažd'ovaniu a výmene dát, tým je aj viac potenciálnych možností kybernetického útoku. Vel'ké množstvo firiem sa však musí venovat' prednostne budovaniu a udržiavaniu digitálnej dôvery.

Čím viac bude do podnikania spoločností zavádzaný ekosystémový prístup, tým bude systém otvorenejší a bude smerovat' do viacerých technologických oblastí. Bezpečnost' musí byt' kompaktnou súčast'ou celého ekosystému, čo pomôže odradit' možných útočníkov a v prípade útoku urýchlit' dobu reakcie.

Podpora bezpečnosti tret'ou stranou je d'alším zo spôsobov, ako zabezpečit' spol'ahlivost' systémov a posilnit' dôveru účastníkov ekosystému v celistvosti celej platformy. $\mathrm{V}$ tomto smere je vel'mi dôležitá aj spolupráca $\mathrm{s}$ partnermi $\mathrm{V}$ rámci ekosystému - rovnomerne rozložené riziká, ako aj zdielanie zodpovednosti za možný útok.

\section{Urýchlenie globalizácie s významnými regionálnymi odlišnost'ami v súvislosti s prechodom na Industry $\mathbf{4 . 0}$}

Štvrtá priemyselná revolúcia spája medzi sebou podniky aj krajiny a v čoraz väčšej miere podporuje globalizáciu cez dátové siete a celosvetové dodávatel'ské ret'azce. 
Vel'a priemyselných lídrov prevádzkuje závody po celom svete, takže úspešná realizácia koncepcie Industry 4.0 nie je obmedzená len na konkrétne krajiny alebo regióny, ale vel'a aplikácií je zároveň previazaných s lokálnymi závodmi, pokial' si charakter výroby vyžaduje rôzne regionálne rozdiely.

Výsledky ukazujú mnohé podobnosti medzi významnými globálnymi spoločnost'ami, ale tiež odlišnosti $v$ rámci jednotlivých regiónov. Podl'a očakávaní by mali $v$ krátkodobom horizonte $z$ Industry 4.0 najviac vyt'ažit' rozvinuté ekonomiky, avšak výsledky ukazujú, že $v$ rozvíjajúcich sa regiónoch sa benefity môžu javit' ešte výraznejšie.

Naviac, zvyšujúce sa mzdové náklady a vysoký potenciál pre digitalizáciu procesov povedie $v$ rozvíjajúcich sa ekonomikách $k$ nadpriemernému zvyšovaniu ukazovatel'ov efektívnosti. Na obrázku 6 je znázornený očakávaný nárast ziskovosti vo všetkých regiónoch.

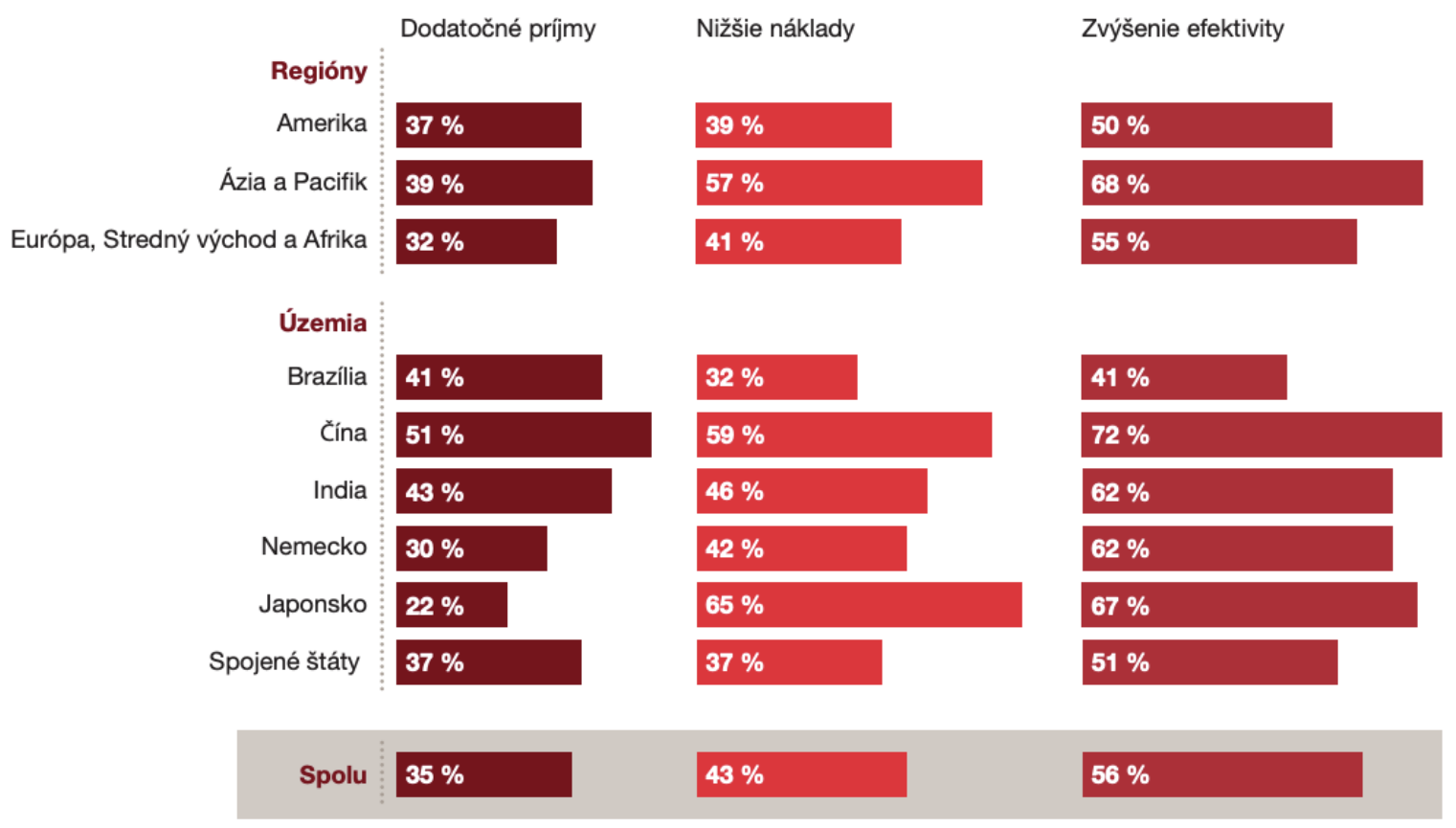

Obrázok 6 - Očakávaný nárast ziskovosti vo všetkých regiónoch [11]

\section{$4 \quad$ Kontrasty medzi regiónmi a krajinami v oblasti Industry 4.0}

Digitalizácia interných operácií a spolupráca naprieč horizontálnym hodnotovým ret’azcom najdalej pokročila $v$ japonských a nemeckých spoločnostiach. Tieto spoločnosti vynakladajú významné investície do technológií a do vzdelávania zamestnancov, pričom digitálnou transformáciou sledujú najmä zvyšovanie prevádzkovej efektívnosti, znižovanie nákladov a lepšie zabezpečenie kvality. 
Americké spoločnosti sa viac orientujú na modifikáciu svojich biznis modelov, väčšie investície vynakladajú do digitalizácie svojich produktov a služieb. Ich ciel'om je skôr rast digitálnych príjmov ako zvyšovanie efektivity.

Čínske priemyselné podniky sa orientujú obidvoma smermi. Čína je jednou z krajín, ktorá by z koncepcie Industry 4.0 mohla získat' najviac, vd'aka automatizácii a digitalizácii výrobných procesov, ktoré sú náročné na pracovnú silu, vzhl'adom na neustály rast mzdových požiadaviek. Okrem toho čínske podniky sú vel'mi flexibilné a otvorené voči digitálnej zmene a čínski pracovníci sú otvorení modernizáciám a novým digitálnym technológiám.

Až $36 \%$ respondentov z ázijskopacifického regiónu je presvedčených, že dosiahli pokročilú úroveň digitalizácie. Takúto úroveň digitalizácie uvádza takmer jedna tretina amerických spoločností (32\%), čo je vel'mi podobné výsledku v regióne EMEA (Európa, Stredný východ a Afrika).

Pri vyhliadke na najbližších pät' rokov sú očakávania týkajúce sa úrovne integrácie a digitalizácie vo všetkých troch regiónoch približne porovnatel'né. Väčšina podnikov očakáva dosiahnutie vysokej úrovne digitalizácie a integrácie, pričom $v$ prípade Japonska a Nemecka táto úroveň prevýši $80 \%$. Americké, francúzske a švédske spoločnosti sa vyznačujú približne podobne vysokým optimizmom.

$\mathrm{Na}$ obrázku 7 sú znázornené spoločnosti po celom svete očakávajúce výrazný nárast digitalizácie $v$ priebehu nasledujúcich piatich rokov.

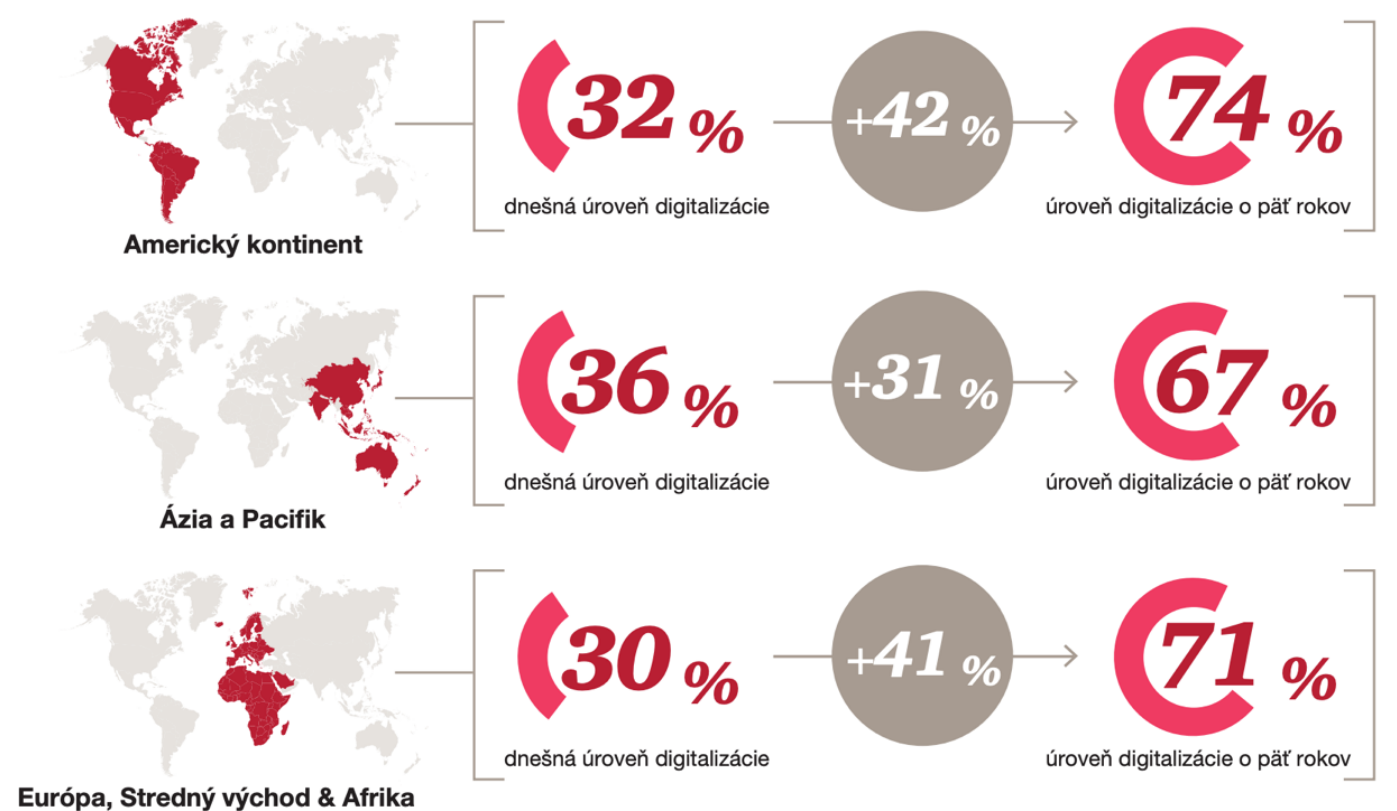

Obrázok 7- Očakávaný výrazný nárast digitalizácie v priebehu nasledujúcich piatich rokov [11]

Industry 4.0 sa neobmedzuje len na horizontálnu a vertikálnu integráciu v rámci organizácie. Súčasné technológie umožňujú lepšie porozumiet' 
potrebám zákazníkov a zvyšovat' hodnotu produktov a služieb prostredníctvom integrovaných inovatívnych riešení.

$\checkmark$ podstate ide o vybudovanie zložitých riešení, ktoré zahŕňajú produkty aj služby. Spoločnosti môžu rozvíjat' spôsob prístupu k zákazníkom v rámci štyroch úrovní - od tradičného spôsobu poskytovania fyzického výrobku, až po vytvorenie komplexného digitálneho ekosystému.

Pokial' sa z akýchkol'vek dôvodov nemôže $v$ rámci organizácie vybudovat' takéto komplexné riešenie prístupu $\mathrm{k}$ zákazníkom, využije sa partnerské riešenie alebo platformy tretích strán. Skutočnú pozitívnu zmenu spozorujeme, ked' aktívne porozumieme správaniu zákazníkov a dokážeme začlenit' našu spoločnost' do ekosystémov partnerov, dodávatel'ov a zákazníkov.

Pretože hodnota takéhoto ekosystému závisí od počtu zúčastnených partnerov a od intenzity ich spolupráce, najväčšou výzvou musí byt' správne nastavenie spôsobov odmeňovania a modely zdielania benefitov. Najzákladnejším biznis modelom je $v$ takomto prípade trhové prostredie, ktoré je zložené z niekol'kých predávajúcich a kupujúcich, ktorí majú vhodne nastavený provízny systém podl'a hodnoty transakcie.

Pre niektoré spoločnosti môže byt' náročné delit' sa o svoje know-how a dajú radšej prednost' vybudovaniu takéhoto ekosystému pomocou rôznych akvizícií.

Na obrázku 8 je znázornený prechod od produktovo na platformovo orientovaný prístup.

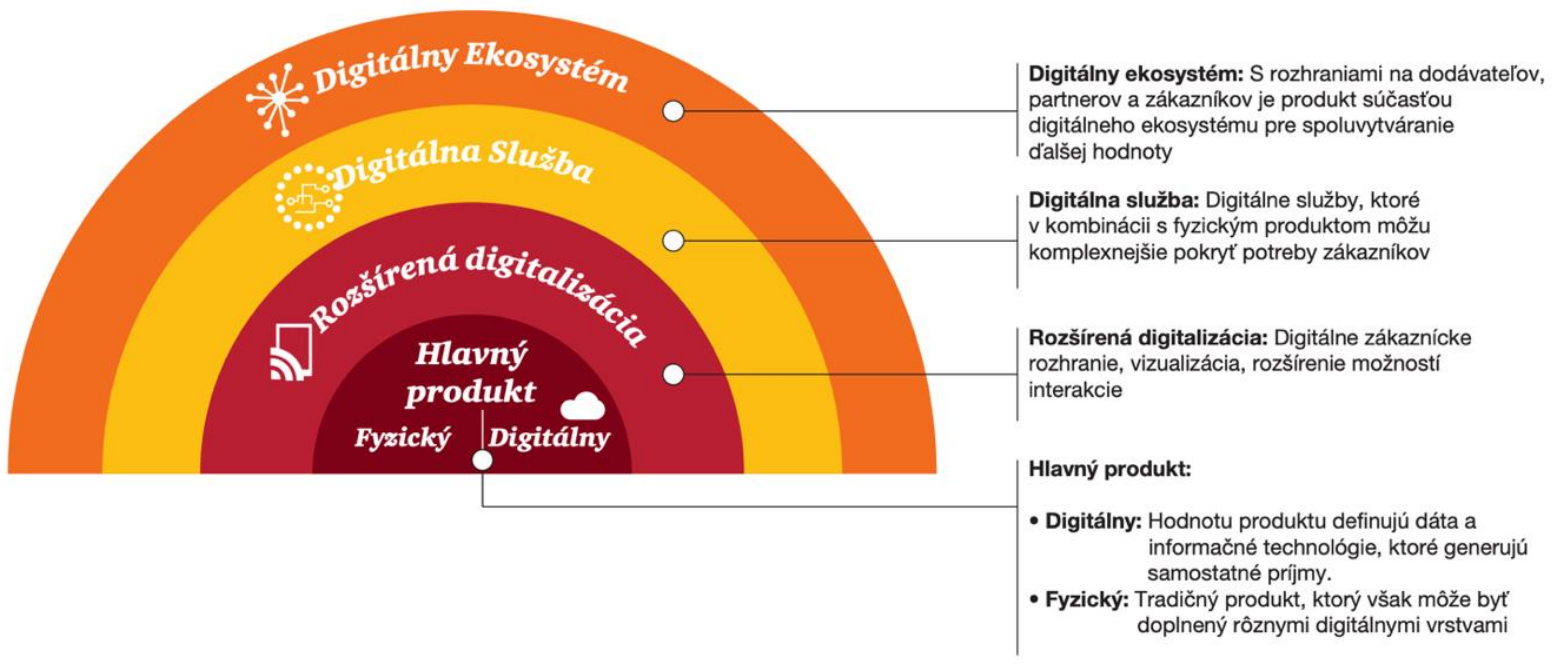

Obrázok 8 - Prechod od produktovo na platformovo orientovaný prístup [11]

\section{Záver}

Priemyselní lídri spolu so svojimi partnermi $v$ rámci horizontálneho hodnotového ret’azca digitalizujú hlavné funkcie svojich interných 
(vertikálnych) prevádzkových procesov. Posilňujú svoje portfólio produktov o digitálne funkcionality a zavádzajú inovatívne dátové služby.

Na konci tohto transformačného procesu sa úspešné priemyselné firmy stanú skutočnými digitálnymi podnikmi, ktorých jadro budú tvorit' fyzické produkty rozšírené o digitálne rozhrania a inovatívne služby založené na aktívnom využívaní dát. Tieto digitálne podniky budú spolupracovat' so svojimi zákazníkmi ako aj dodávatel'mi v priemyselných digitálnych ekosystémoch. Tento vývoj nielenže zásadne zmení jednotlivé spoločnosti, ale taktiež transformuje dynamiku trhu $v$ celom rade priemyselných odvetví. [2]

\section{Pod'akovanie}

Príspevok bol riešený $v$ rámci projektu 002TUKE-4/2020 Implementácia inteligentnej techniky a pokrokových technológií pre podporu transformačných procesov a projektovanie výrob budúcnosti a VEGA 1/0438/20 Interakcia digitálnych technológií za účelom podpory softvérovej a hardvérovej komunikácie pokročilej platformy systému výroby.

\section{Použitá literatura}

[1] DOMBROWSKI, U., RICHTER, T., KRENKEL, P. (2017). Interdependencies of Industrie 4.0 \& lean production systems: A use cases analysis. Procedia Manufacturing. 2017, 11, 1061-1068. ISSN 2351-9789.

[2] ILLÉS, B., GLISTAU, E., MACHADO, N. I. C. Logistik und Qualitätsmanagement. Miskolc: University of Miskolc, 2007. 195 s. ISBN 978-877-3814.

[3] JOLY, M., ODLOAK, D., MIYAKE, M. Y., MENEZES, B. C., KELLY, J. D. Refinery production scheduling toward Industry 4.0. Frontiers of Engineering Management. 5(2), 202-213. ISSN 2096-0255.

[4] LOPEZ, P., ROUBELLAT, F. Production scheduling. John Wiley \& Sons: USA, 2013. 384 s. ISBN: 978-1-118-62402-9.

[5] MAYR, A., WEIGELT, M., KÜHL, A., GRIMM, S., ERLL, A., POTZEL, M., FRANKE, J. Lean 4.0-A conceptual conjunction of lean management and Industry 4.0. Procedia Cirp. 2018, 72, 622-628. ISSN 2212-8271.

[6] MRUGALSKA, B., WYRWICKA, M. K. Towards lean production in industry 4.0. Procedia engineering. 2017, 182, 466-473. ISSN 1877-7058.

[7] NAGY, G., TÓTH, Á. B., ILLÉS, B., GLISTAU, E. Analysis of supply chain efficiency in blending technologies. In Vehicle and Automotive Engineering. Springer, Cham. 2018. p. 280-291. ISBN 978-3319-7567-69.

[8] NICHOLAS, J. Lean production for competitive advantage: a comprehensive guide to lean methodologies and management practices. Boca Raton: Crc press, 2018. 613 s. ISBN 978-1498-7808-89. 
[9] PARENTE, M., FIGUEIRA, G., AMORIM, P., MARQUES, A. Production scheduling in the context of Industry 4.0: Review and trends. International Journal of Production Research. 2020, 58(17), 5401-5431. ISSN 0020-7543.

[10] ZHANG, A. Quality improvement through Poka-Yoke: from engineering design to information system design. International Journal of Six Sigma and Competitive Advantage. 2014, 8(2), 147-159. ISSN 1479-2494.

[11] HNÍZDILOVÁ, N. Rozvrhovanie výroby v kontexte prechodu na Industry 4.0. Košice, 2021. Diplomová práca. Technická univerzita v Košiciach. Strojnícka fakulta. 